\title{
On attracting investment to Russian economy
}

\author{
Elena Oleinik ${ }^{1, *}$ \\ ${ }^{1}$ Department of Business Informatics and Economics and Mathematical Methods, Far Eastern Federal University, Vladivostok, \\ Russia
}

\begin{abstract}
Modern conditions of economic systems development have necessitated more precise directions of investment process for the economic growth to accelerate. The precipitous fall of oil prices that occurred in the second half of 2014 weighed heavily on foreign direct investment flows to oilexporting countries. The problem of attracting investment is one of the key problems of economic development. The aim of this study is to analyze and evaluate the shifts in the structure of investments, the study of the structure of investments to the Russian economy. Structural changes result from differences in the growth rate of the elements forming an economic system. An integral coefficient has been used for evaluation of structural changes. Multiple regression was used to analyze the impact of various factors on the change in structure of investment. The regression coefficients in the model give quantitative assessment of the pace of change in the structure as it depends on a specific factor. The model estimation shows that the variables "share of investments in manufacturing" (positive influence) and "share of investments in the health, physical culture, education" (negative influence) have the largest t-values. Hence, these two factors influence the structural changes in investments most strongly The evaluation and analysis of the structural shifts may lead to conclusions regarding the efficiency of the structure investment and adjustment of the economic policy.
\end{abstract}

\section{Introduction}

The intensity of economic growth is largely determined by active investment activity, and the problem of attracting investment is one of the key problems of economic development. Russia possesses all major factors determining investment attractiveness of the area, such as high level of potential demand at the domestic and international markets, significant reserves of natural resources, well-developed industrial enterprises management structure, available energy resources, production and social infrastructure in the NorthWestern and Siberian territories, available land and sea transportation routes, possibility of all-year-round supply of products. Foreign investments inflow is vital for overcoming current crisis situation and for economic revival. Rating of countries according to the total volume of attracted investments is presented in the table 1 . The precipitous fall in oil prices that occurred in the second half of 2014 weighed heavily on foreign direct investment (FDI) flows to oil-exporting countries. Countries use different concepts of national security, allowing them to take into account key economic interests in the investment screening process. Governments' space for applying national security regulations needs to be balanced with investors' need for transparent and predictable procedures. However, this growth did not translate into an equivalent expansion in productive capacity in all countries.
Table 1. Rating of countries according to the total volume of attracted investments.

\begin{tabular}{|c|c|c|c|c|c|}
\hline \multirow{2}{*}{$\begin{array}{c}\text { Total } \\
\text { volume of } \\
\text { attracted } \\
\text { investment } \\
\text { s (Millions } \\
\text { of dollars) }\end{array}$} & \multicolumn{3}{|c|}{$\begin{array}{c}\text { Years } \\
\text { (Millions of dollars) }\end{array}$} & \multirow{2}{*}{$\begin{array}{l}\text { Cumulativ } \\
\text { e volume } \\
\text { of } \\
\text { attracted } \\
\text { investment }\end{array}$} & \multirow{2}{*}{$\begin{array}{c}\text { Average } \\
\text { growth } \\
\text { rate }\end{array}$} \\
\hline & 2013 & 2014 & 2015 & & \\
\hline USA & 231 & 92 & 380 & 703 & 2,03 \\
\hline PRC & 124 & 129 & $\begin{array}{c}13 \\
6\end{array}$ & 389 & 1,03 \\
\hline Canada & 71 & 59 & 49 & 174 & 0,95 \\
\hline $\begin{array}{c}\text { Russian } \\
\text { Federation }\end{array}$ & 69 & 21 & $\begin{array}{l}1 \\
0\end{array}$ & 100 & 0,69 \\
\hline
\end{tabular}

Source: Calculated by the author based on data [1]

The Russian Federation in 2015 recorded FDI flows of $\$ 9.8$ billion, a 66 per cent contraction from the previous year. FDI flows were mainly in the form of reinvested earnings, as new FDI flows almost dried up. Falling oil prices and geopolitical tensions continued to damage economic growth prospects and erode investor interest in the country

The crisis in the Russian economy affects the changes in investment levels and there is a trend of investment reduction in joint ventures. Foreign investors

\footnotetext{
Corresponding author: oleynik.eb@dvfu.ru
} 
are not keen to invest in the development of products with high added value, thus creating competitive products and jobs on the territory of our country. At the same time, Russian economic interests do not always match interests of foreign investors. Investment attraction is vital for integration of Russia into the world economy. However, the question arises: how to evaluate the result of investment policy and investment efficiency?

In the process of implementation of investment projects aimed at economic development of the country and the regions, special transformations take place i.e. the change of economic structure: changes are observed in the ratio of shares and proportions as well as in the direction and strength of the links between its elements. Modern science continues generating unabated interest in the study of problems and identifying patterns of structural shift, their focus, the interdependence between the level of development of the economy and its structure.

\section{Literature Review}

Select the main factors of factors influencing FDI activity [2-4]

- Macroeconomic and policy factors: regional agreements such as TPP, RCEP, TTIP; changes in tax regimes; commodity prices, including oil; changes in global financial regulations; exchange rate volatility; geopolitical uncertainty; debt concerns in emerging markets.

- Corporate and external factors: technological change, including digital economy; global urbanization; offshore outsourcing of corporate operations; energy security; food security; climate change; migration; cyber threats and data security.

Can be divided countries on two group: investors and recipients. The host country determinants for FDI consist of (a) the general policy framework for foreign investment, including economic, political and social stability, the gislation affecting foreign investment and any other policies affecting FDI locational decisions; (b) economic determinants, such as the market size, cost of resources and other inputs or the availability of natural resources; and (c) business facilitation, including investment promotion. All three groups of determinants interact, enhancing or reducing the attractiveness of countries to foreign investment [5].

Scientific literature provides various approaches to the definition of the category of 'structural shifts'.

-a structural shift is a qualitative change in the relationships between comparable elements of an economic system caused by uneven dynamics of the ratio between their quantitative characteristics. Comparable elements are referred to as elements which belong to the same level or segment of an economic system. A structural shift in the economic system of a higher level cannot be reduced to a simple arithmetic sum of its components [6];

- a structural shift is the change of the internal structure of the economic system, the relationship between its elements, which are accompanied by the transformation of the main (integrated) system properties [7-8].

A structural shift means a change of proportions of the economic system, which occurs under the influence of the structure-forming factors. Structural changes are associated with the intensification of production [910].This definition implies that any change in the structure can be seen as a structural shift, which is regarded as the accumulation of imbalances. Changes in the structure of the economy represent a complex system of interrelated changes in the proportions taking place under the influence of the existing technical basis, social mechanisms of production, distribution and exchange, in accordance with social needs, available resources and the achieved level of productivity [11].Structural changes are a certain difference between the new and the old structures, which reflects not only the difference in the organization of production, but also the development of the entire system of economic relations.

Despite the fact that the definition of 'a structural shift' was highlighted in a great number of studies done by Russian and foreign economists, a single definition has not been formulated and subordination between the notions of 'structural shift' and 'structural change' has not been elaborated. The classification of indicators of structural changes is proposed in [12] and completed in [13]. Structural changes of economy under the influence of various factors are investigated and explained in [1417].

A sufficient number of various indicators used to evaluate the structural shift describes in the literature, but only some of them contain the scale of values and recommendations for using them.

- in [18]: chain and basic index is used the higher the value of the chain index, the more intensively structural shifts occur, and vice versa. The basic index serves as an indication of the extent of the tendency which underlies the structural shifts, and to what extent they are merely the result of irregular fluctuations.

- in [19]: the integrated coefficient that considers the intensity of the changes by individual group and the proportion of groups in comparable structures. L. Kazinets15 Absolute and relative growth rate and the shift intensity. The coefficients indicate the intensity of shifts, but do not give a qualitative characteristic of the processes taking place.

- in [20]: integrated coefficient of structural differences does not depend on the number of gradations of aggregate structure. The author suggests an evaluation scale for measuring importance of structural differences.

- in [21]: the intensity of structural shifts (taking values from 0 to 1 ) is evaluated through the change in the angular distance between the vectors of economic structure in the initial and final periods.

- in [22]: the importance of the structural transformation evaluates the index, $\lambda$ the evaluation is considered to be significant if the value of the index is significant $\lambda$ (a change of $15 \%$ in the index $\lambda$ over 5 years)

The article [21-22] presents a comparative analysis approaches to determining the investment activity and to 
evaluation of the role of investments in achieving a steady economic advance.

But are these changes in the structure of the positive? Does GDP depending on the integrated shifts?

\section{Research Methods}

The considered existing evaluation indicators do not allow for a comprehensive study of structural shifts and measuring the proportions between the structural elements. In our opinion, complex evaluation of shifts in the structure of investments requires a combination of some of the methods. Table 2 presents basic approaches, areas of research, types and methods of analysis of structural changes in investment flows.

We offer a comprehensive, step-by-step methodology for the analysis and evaluation of structural shifts.

1. The choice of the study period and the definition of the input parameters. Input parameters: $f_{j}-$ the relative weight of j-element of the structure in the current $(l)$ and previous (l-1) periods; $n$ - the number of structural elements.

2. Calculation of linear structural shifts (formula 1), that show absolute changes in the relative weight of each element of the structure, but do not give the qualitative characteristics of the processes.

$$
S_{j}^{a b s}=f_{j}^{l}-f_{j}^{l-1}=\Delta f_{j}
$$

3. Calculation of the quadratic structural shifts (formula 2), that are calculated based on linear structural shifts. Sabs coefficient allows for getting a summary assessment of the total speed of branch shifts, and Srelat for each j-element of the structure. It is coefficient of uniformity of structure (formula 3 ). Treated dynamically, these coefficients characterize the trend of change in the industrial structure

$$
\begin{aligned}
S_{a b s} & =\sqrt{\frac{\sum_{j=1}^{n}\left(f_{j}^{l}-f_{j}^{l-1}\right)^{2}}{n}} \\
S_{j}^{\text {relat }} & =\frac{f_{j}^{l}-f_{j}^{l-1}}{f_{j}^{l-1}} * 100 \%
\end{aligned}
$$

4. Calculation of intensity of structural shifts of a branch and branch structure as a whole. Intensity coefficient characterizes the importance of structural shifts $[9,10]$. The intensity of structural shifts (taking values from 0 to 1 ) is evaluated through the change in the angular distance between the vectors of economic structure in the initial and final periods. Sudden changes in intensity coefficients over time indicate instability and uneven development of structural elements.

$$
K_{\mathrm{int}}=\frac{f_{j}^{l}}{f_{j}^{l-1}} * 100 \%
$$

5. Calculation of integral structural shifts. Integrated coefficient allows for evaluating the structural differences: the closer the I to 1, the more significant the structural changes are and, therefore, the differences in the structure.

$$
I_{l}=\sqrt[n]{\Pi_{j=1}^{n} f_{j}^{l}}
$$

6. Evaluation of the significance of structural changes

$$
\mathrm{m}_{\mathrm{l}}=\sqrt{\frac{1-\mathrm{I}_{1}^{2}}{\mathrm{n}-1}} \quad \text { and } \quad \mathrm{t}_{\mathrm{l}}=\frac{\mathrm{I}_{1}}{\mathrm{~m}_{\mathrm{l}}}
$$

If structural changes are significant (ti $>\mathrm{ttab} ; \mathrm{ttab}==$ $2,13)$, there is a structural shift

Output parameters are a set of integrated assessments of the state and dynamics of the structure.

The proposed method allows a comprehensive analysis of the nature of structural shifts, their interaction and orientation, and thus enables us to evaluate the presence of distortions as well as quantitative and qualitative structural changes.

In the modern economic science, a rather universal approach to construction of econometric models of the economic growth is described, and the following equation is formed in general terms [25]

$G R=a_{0}+\sum a_{i} E k_{i}+\sum b_{j} C V a r_{j}+\sum c_{l}$ Dum $_{l}+\varepsilon_{k}(7)$

Here: $G R$ - growth rate of the main indices of the national product in the country; $E k_{i}$ - economic variables; $C V a r_{j}$ - additional control variables; Dum $_{l}-$ dummy variables reflecting the regional effect; a 0 constant; $a_{i}, b_{j}, c_{l}-$ the respective regression coefficients; $\varepsilon \mathrm{k}$ - random error. The econometric approach is based on adding a set of variables describing the economy's structural parameters into the right part of the equation (7). We are following this approach too when studying the influence of investments in the fixed capital on the economic growth rates.

\section{Results}

The model suggested was tested out on statistical data provided by the Russian Federal service of the state

\begin{tabular}{|c|c|c|c|c|}
\hline \multirow[b]{2}{*}{ Year } & \multirow{2}{*}{$\begin{array}{l}\text { GDP, in } \\
\text { percent to the } \\
\text { previous year } \\
\text { (at constant } \\
\text { prices) }\end{array}$} & \multicolumn{2}{|c|}{ Structural shifts, share } & \multirow{2}{*}{$\begin{array}{c}\text { Signifi } \\
\text { cance of } \\
\text { integrated } \\
\text { shift }\end{array}$} \\
\hline & & quadratic & integrated & \\
\hline 1996 & 145.8 & 0.646 & 0.441 & 1.538 \\
\hline 1997 & 115.1 & 0.430 & 0.366 & 1.317 \\
\hline 1998 & 118.6 & 1.873 & 1.081 & 5.429 \\
\hline 1999 & 172.5 & 2.010 & 1.324 & 6.302 \\
\hline 2000 & 110 & 2.013 & 0.897 & 5.117 \\
\hline 2001 & 81.7 & 0.492 & 0.775 & 3.211 \\
\hline 2002 & 104.7 & 1.074 & 0.640 & 2.310 \\
\hline
\end{tabular}
statistics for 1994-2016. The results of calculations in accordance with the suggested methodology are presented in Table 2. Significant integrated shifts marked in bold.

Table 2. Evaluation of structural shifts. 


\begin{tabular}{|l|r|r|r|r|}
2003 & 107.3 & 0.522 & 0.740 & $\mathbf{2 . 9 2 3}$ \\
\hline 2004 & 107.2 & 0.620 & 0.423 & 1.483 \\
\hline 2005 & 106.4 & 0.758 & 0.416 & 1.462 \\
\hline 2006 & 107.7 & 0.552 & 0.640 & $\mathbf{2 . 3 1 0}$ \\
\hline 2007 & 108.1 & 0.606 & 0.291 & 1.110 \\
\hline 2008 & 105.2 & 0.269 & 0.394 & 1.395 \\
\hline 2009 & 92.2 & 0.406 & 0.303 & 1.141 \\
\hline 2010 & 104.5 & 0.512 & 0.376 & 1.345 \\
\hline 2011 & 104.3 & 0.173 & 0.132 & 0.674 \\
\hline 2012 & 103.4 & 0.480 & 0.228 & 0.941 \\
\hline 2013 & 101.3 & 0.638 & 0.322 & 1.195 \\
\hline 2014 & 95.5 & 0.644 & 0.667 & $\mathbf{2 . 4 5 2}$ \\
\hline 2015 & 101.2 & 1.310 & 0.364 & 1.310 \\
\hline
\end{tabular}

High coefficients indicate uneven structural changes. Their speed and importance allow us to assess quadratic and integrated coefficients. Maximum speed of restructuring and significant differences in the structure of investments was observed in 2000 and 2015. The structure of investments was stable in 2000-2014 (fig.1), the regression coefficient approximately equal to zero (0.004).

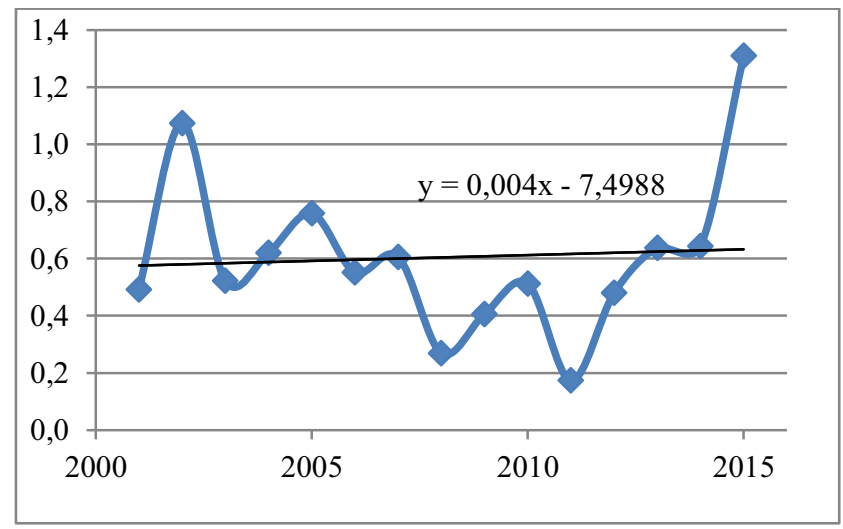

Fig. 1 Regression of an integral structural shift.

Additional calculations are required for a consolidated and integrated assessment of structure dynamics. The correlation coefficient $\mathrm{R}_{\mathrm{YX} 2}=0.49$, therefore there is a relatively strong linear dependence. The results regression modeling are presented in Table 3. $\mathrm{Y}$ is the endogenous variable, GDP growth.

Table 3. Results of regression modeling.

\begin{tabular}{lr}
\hline \multicolumn{2}{c}{ Regression statistics } \\
\hline Multiple R & 0.481907 \\
$\mathrm{R}^{2}$ & 0.232235 \\
Standardized $\mathrm{R}^{2}$ & 0.189581 \\
Standard error & 17.43214 \\
Observations & 20 \\
\hline
\end{tabular}

\begin{tabular}{|c|c|c|c|}
\hline \multicolumn{4}{|c|}{ Dispersion analysis } \\
\hline & $d f$ & $F$ & \\
\hline Regression & 1 & 5,4446 & \\
\hline Remainder & 18 & & \\
\hline Total & 19 & & \\
\hline & $\begin{array}{l}\text { Regression } \\
\text { coefficients }\end{array}$ & $\begin{array}{c}t- \\
\text { statistics }\end{array}$ & Pvalue \\
\hline Y-crossing & 92.72401 & 11.397 & $1.15 \mathrm{E}-09$ \\
\hline
\end{tabular}

\begin{tabular}{llll} 
Integrated shift & 30,80066 & 2,333 & 0,0314 \\
\hline
\end{tabular}

The model is valid according to Fisher's test. Regression coefficient is valid according to Student's test and positive, therefore, their increase enhances the economic growth. The regression model can be used to predict.

The following designations are used: for share of investments: $Z 1$ - in manufacturing; $Z 2$ - in extractive industries; Z3 - in scientific research and development; Z4 - in the health, physical culture, education. Multiple regression was used to analyze the impact of various factors on the change in structure of investment (Table 4). $\mathrm{Y}$ is the endogenous variable, integral shift/

Table 4. Results of multiple regression modeling.

\begin{tabular}{|c|c|c|c|}
\hline \multicolumn{2}{|c|}{ Regression statistics } & & \\
\hline Multiple R & 0.800771 & & \\
\hline $\mathrm{R}^{2}$ & 0.641235 & & \\
\hline Standardized $\mathrm{R}^{2}$ & 0.545564 & & \\
\hline $\begin{array}{l}\text { Standard error } \\
\text { Observations }\end{array}$ & $\begin{array}{r}0.204238 \\
20\end{array}$ & & \\
\hline \multicolumn{4}{|c|}{ Dispersion analysis } \\
\hline & $d f$ & $F$ & \\
\hline Regression & 4 & 6.702523 & \\
\hline Remainder & 15 & & \\
\hline \multirow[t]{2}{*}{ Total } & 19 & & \\
\hline & $\begin{array}{l}\text { Regression } \\
\text { coefficients }\end{array}$ & $\begin{array}{c}t- \\
\text { statistics }\end{array}$ & Pvalue \\
\hline Y-crossing & 0.2723 & 0.2618 & 0.7971 \\
\hline $\mathrm{Z1}$ & 0.1823 & 4.5158 & 0.0004 \\
\hline $\mathrm{Z} 2$ & -0.0494 & -1.4582 & 0.1654 \\
\hline $\mathrm{Z3}$ & -0.5734 & -1.9161 & 0.0746 \\
\hline Z4 & -0.3485 & -2.2577 & 0.0393 \\
\hline
\end{tabular}

The regression coefficients in the model give quantitative assessment of the pace of change in the structure as it depends on a specific factor. The model estimation shows that the variables "Z1 -share of investments in manufacturing " (positive influence) and "Z4 - share of investments in the health, physical culture, education " (negative influence) have the largest t-values. Hence, these two factors influence the structural changes in investments most strongly.

Regression coefficients for Z2-Z4 is not valid according to Student's test. The regression model cannot be used to predict. But we can to use regression coefficients for calculation of elasticity coefficients. The following designations are used: $\mathrm{S}$ - elasticity coefficient; Y - integral structural shifts of investment. The elasticity coefficients (as a percentage) are:

$$
\begin{aligned}
& \mathrm{S}_{\mathrm{YZ1}}=+5,06 ; \quad \mathrm{S}_{\mathrm{YZ} 2}=+1,38 ; \\
& \mathrm{S}_{\mathrm{YZ3}}=-0,65 ; \mathrm{SY}_{\mathrm{Z} 4}=-2,55 \text {. }
\end{aligned}
$$

Additional investments in the manufacturing industry increase the integral structural shift by 5,06 percent, which provides growth of GDP. 


\section{Discussion}

Based on analysis of detected problems and situation evaluation, we consider it necessary to take the following steps in order to attract investments into the Russian economy:

First: improvement of investment climate. Attraction investors is important to create favorable investment climate, that is environment where investment processes take place. To improve the investment climate, the following measures are required to take: creation of insurance investment funds with government participation; stimulation of partner agreements, according to which foreign investor supplies machinery, equipment, technologies, complete plants in exchange of counter deliveries of raw materials and semi-finished goods produced at the supplied equipment; attraction of foreign financial resources in the form of compensation agreements, that is credits which return basis is supply of products made by created enterprise; establishing of favorable tax regime, lowering of electrical energy and transportation tariffs; organization of presentations for priority investment projects; providing by the enterprises of reliable and transparent information, as well as government control over schedule times for priority investment projects; ensuring property protection and investor personal safety.

Second: improvement of economic, as well as regulatory and legal framework for public-private partnership (PPP). The government, entering into alliance with business, obtains not only its financial resources and easing of budget burden, but also more flexible system of project management. Business is also interested in utilization of government resources, guarantees and preferences to solve its tasks. Publicprivate partnership is a tool of active government interference in the economy with the purpose of elimination and prevention of structural disproportions

Third: development of leasing scheme of investment attraction: establishing of pledge funds to ensure bank investments in leasing with the use of state property; improvement of legal and regulatory framework to protect the interests of leasing deals participants; establishing of state guarantee fund for export when making international leasing of domestically produced machinery and equipment.

The conducted analysis reveals that, in spite of the fact that the volume of investments into the economy of Russia for the period from 1996 to 2015 increased more than threefold, imbalances remain in the structure of investments.

Investors do not invest in the development of the regions of Russia. Short-term investments are aimed at fast and risk-free return on investment. The regions are mainly focused on the production and export of raw materials, rather than processing them, which reduces the level of its economic development. It follows that there are serious problems of attracting investments.

\section{Conclusion}

Our offers per main areas and methods of investing are shown at the table 5. All these measures will help to attract investments, improve the structure efficiency and economic growth of Russia.

Table 5. Main areas, sources and methods of investment activity.

\begin{tabular}{|c|c|c|}
\hline Area & Sources & Methods \\
\hline $\begin{array}{l}\text { Development of } \\
\text { new technologies } \\
\text { in the processing } \\
\text { industry }\end{array}$ & $\begin{array}{l}\text { Targeted budget } \\
\text { financing } \\
\text { Extrabudgetary } \\
\text { funds }\end{array}$ & $\begin{array}{l}\text { Venture financing } \\
\text { Government subsidies }\end{array}$ \\
\hline $\begin{array}{l}\text { Reconstruction of } \\
\text { enterprises }\end{array}$ & $\begin{array}{l}\text { Enterprises' own } \\
\text { financial means } \\
\text { Bank credits }\end{array}$ & $\begin{array}{l}\text { Leasing } \\
\text { Project financing } \\
\text { Public-private } \\
\text { partnership in the } \\
\text { form of top priority } \\
\text { investment projects } \\
\text { Concession } \\
\text { agreements } \\
\text { Additional emission } \\
\text { of shares } \\
\text { Compensation } \\
\text { agreements }\end{array}$ \\
\hline $\begin{array}{l}\text { Creation of } \\
\text { enterprises with } \\
\text { high added value: } \\
\text { vertically } \\
\text { integrated } \\
\text { structures and } \\
\text { raw materials } \\
\text { deep processing } \\
\text { enterprises }\end{array}$ & $\begin{array}{l}\text { Share capital } \\
\text { Targeted bank } \\
\text { credits and loans } \\
\text { Investment } \\
\text { credits }\end{array}$ & $\begin{array}{l}\text { Public-private } \\
\text { partnership in the } \\
\text { form of top priority } \\
\text { investment projects } \\
\text { Corporatization of } \\
\text { enterprises } \\
\text { Bonds issue } \\
\text { Compensation } \\
\text { agreements }\end{array}$ \\
\hline $\begin{array}{l}\text { Development of } \\
\text { social } \\
\text { infrastructure of } \\
\text { cross-industry } \\
\text { complexes and } \\
\text { road networks }\end{array}$ & $\begin{array}{l}\text { Targeted budget } \\
\text { financing } \\
\text { Bank credits } \\
\text { Enterprises' own } \\
\text { financial means } \\
\text { Mortgage loans } \\
\text { Concessionary } \\
\text { loan }\end{array}$ & $\begin{array}{l}\text { Outsourcing } \\
\text { Public-private } \\
\text { partnership in the } \\
\text { form of top priority } \\
\text { investment projects } \\
\text { Implementation of } \\
\text { federal targeted } \\
\text { programs of territories } \\
\text { development }\end{array}$ \\
\hline
\end{tabular}

The proposals and approaches to improve the efficiency of the investment policy in the Russia, as well as the method for analysis of investment structure can serve as a basis for further theoretical and applied research in the field of regional investment policy.

\section{References}

1. J.X. Zhan, R. Bolwijn, K. Byun, B. Casella, World Investment Report: Investor nationality: policy challenges (New York, 2016). http://unctad.org/en/PublicationsLibrary/wir2016 en . $\mathrm{pdf}$

2. P. Nunnenkamp, J. Spatz, Transnational Corporations, 11, 1-34 (2002)

3. A.A. Sultygova, L.G. Popov, Actual problems of humanitarian and natural Sciences, 3, 85-88 (2016) 
4. E. Aisbett, Bilateral investment treaties and foreign direct investment: Correlation versus causation (University of California, Berkeley, 2007). http://repositories.cdlib.org/are.ucb/1032.

5. The Role of International Investment Agreements in Attracting Foreign Direct Investment to Developing Countries materials of conference United Nations Conference on Trade and Development New York and Geneva (2009). http://unctad.org/en/Docs/diaeia20095 en.pdf

6. A. Szirmai, Industrialization as an Engine of Growth in Developing Countries (2009). http://www.merit.unu.edu/publications/wppdf/2009/ wp2009-010.pdf.

7. J. Meckl, Journal of Economics, 77(3), 241-266 (2002)

8. J. Laitner, Review of Economic Studies, 67, 5455619 (2000)

9. C. Greenhalg, M. Gregory, Oxford Bulletin of Economics and Statistics, 63, 629-646 (2001)

10. F. Caselli, I.I. Coleman, John Wilbur, A Reinterpretation. Journal of Political Economy, 109(3), 584-616 (2001)

11. E.M. Urkunchiev, Structural shifts in the economy of Kazakhstan: theory, methodology, movement (Turkestan, 2010)

12. L.S. Kazinets, Growth and structural change in the economy (Performance planning and review process) (Economy, Moscow, 1981)

13. N.P. Perstenyova, Basic Research, 2, 478-82 (2012)
14. A. Greenspan, Vital Speeches of the Day, 5(67), 130-4 (2000)

15. B. Los, The impact of research and development on economic growth and structural change (Universiteit Twente, 2000)

16. I.K. Shevchenko, Y.V. Razvadovskaya, World Applied Sciences Journal, 28(6), 860-5 (2013)

17. Y.D. Weissman, V.O. Boos, Regional economy, 4, 208-19 (2013)

18. V.A. Bessonov, HSE Economics Journal, 2, 184$219(2000)$

19. K. Gatev, Statistical evaluation of the differences between structures. Theoretical and Methodological Problems of Statistics (Statistics, Moscow, 1979)

20. V.M. Ryabtsev, G.I. Chudilin, Regional statistics, (Moscow, Finance and Statistics, 2001)

21. O.V. Spasskaya, MAX Press, 20-39 (2003)

22. L.A. Dedov, V.F. Kapustin, Bulletin of St. Petersburg University, 95-103 (1995)

23. E. Oleinik, A. Zakharova, International Journal of Economics and Financial Issues. Special Issue for Fundamental and Applied Research in Economics and Management: New Perspectives, 6(S8), 340-345 (2016)

24. E. Oleinik, A. Zakharova, Indian Journal of Science and Technology, 9(36), 1-7 (2016). DOI: 10.17485/ijst/2016/v9i36/102025

25. R.J. Barro, X. Sala-i-Martin, Economic Growth (The MIT Press, Cambridge, 2003) 